\title{
Reference Document
}

National Cancer Institute

\section{Source}

National Cancer Institute. Reference Document. NCI Thesaurus. Code C41117.

A document that provides pertinent details for consultation about a subject. 